$17^{\text {th }}$ International Congress of Metrology, 07006 (2015)

DOI: $10.1051 /$ metrology $/ 201507006$

(C) Owned by the authors, published by EDP Sciences, 2015

\title{
Perfecting methods of metrological traceability of priority air pollutants using UV absorption spectroscopy
}

\author{
L.Konopelko $^{1,2, a}$, V.Beloborodov ${ }^{1,2}$, D.Rumiantsev ${ }^{1}$ and D.Selukov ${ }^{1}$ \\ ${ }^{1}$ D.I.Mendeleyev Metrology Institute (VNIIM), 190005, 19 Moskovsky ave., St. Petersburg, Russia \\ ${ }^{2}$ University of Information Technologies, Mechanics and Optics, 197101, 49 Kronverksky ave., St. Petersburg, Russia
}

\begin{abstract}
Résumé. Developpement des méthodes de transfert de fraction molaire et de la concentration en masse du polluants gazeux de la part de Etalon Primaire de Mesurage d'Etat dans une Ambiance Gazeux (GET 154-2011 [1]) à étalons de travail de zero et premiere catégorie (materiau de reference) à la base de méthodes de la spectroscopie absorption en UV.
\end{abstract}

\section{Introduction}

At present in Russia about thirty factories manufacture working standards of gas mixtures in total quantity over 70,000 cylinders a year.

Many efforts have to be completed to ensure the traceability of measurement by achieving metrological traceability from the National Primary Measurement Standard of Mole Fraction and Mass Concentration of Components in Gas Media (GET 154-2011) [1,2] to working standards. At present traceability of mole fraction and mass concentration of components is realized by means of comparison standard (CS) which are needed to transfer units to working standards. The need of CS is about 1000 cylinders a year and that is a serious burden for the GET 154-2011.

Development of new certification procedures for CS and further for working standards have to be completed to decrease the number of CS and to increase an accuracy of transference of mole fraction from the GET 154-2011.

The aim of presented exploration was perfecting methods of transference of mole fraction and mass concentration of priority air pollutants $-\mathrm{Cl}_{2}, \mathrm{SO}_{2}, \mathrm{H}_{2} \mathrm{~S}$, $\mathrm{NO}$ (some results for $\mathrm{Cl}_{2}$ and $\mathrm{NO}$ are presented in this paper) to increase accuracy of transference based on methods of UV absorption spectroscopy from GET 154-2011 to 0-th grade and 1-st grade working standards. Besides, another aim of this exploration was investigation of the possibility of metrological assurance of measurement traceability in the field of gas analysis carried out without CS.

GEISA [3] and HITRAN [4] are the mostly used and internationally recognized spectroscopic databases. But unfortunately they do not have data on many substances in UV spectral region.

Cross sections of gases in UV could be found e.g. in DB of Jet Propulsion Laboratory [5] and in DB of Max Planck Institute [6].

Comparison of different sources of information in UV gives an understanding that there are considerable discrepancies between cross sections taken at the same wavelength and under the same temperature from different sources of information.

\section{Analysis of metrological characteristics of UV spectrophotometer used in our laboratory}

There was developed a procedure to get a high accuracy spectroscopic parameters of $\mathrm{Cl}_{2}$ by the UV spectrometers (further in text - procedure [7]). The procedure provides obtaining experimental data with the use of optical filters for measuring a level of scattered light and with the use of a cell with mercury vapor for getting an instrument function. There was conducted an analysis of performance attributes and metrological characteristics of UV spectrophotometer Varian Cary 5000 (spectral range $175-3300 \mathrm{~nm}$, spectral resolution $<0.048 \mathrm{~nm}$ in UV). Estimations of signal/noise ratio, scattered light level, spectral resolution, absolute error of wavenumber scale, error of absorption scale, and error of an instrument function were done. The spectrum was measured to get a form of the instrument function which apparently has a triangle form.

\section{Procedure}

The procedure [7] provides a certification of two components CSs in cylinders under pressure.

The procedure makes a provision for measurements of mole fraction in gas mixtures by the UV spectrometry at the given wavelength and given spectral resolution conducted on the Cary 5000 spectrophotometer which is included in a UV-IR spectrometric installation of the national primary measurement standard GET 154-2011.

According to the procedure gas mixture from a cylinder under pressure is forwarded in a gas cell installed in a spectrophotometer and the transmission $\mathrm{T}$ is measured. The transmission spectra of $\mathrm{Cl}_{2}$, and $\mathrm{NO}$ are presented in fig 1 and fig 2 correspondently.

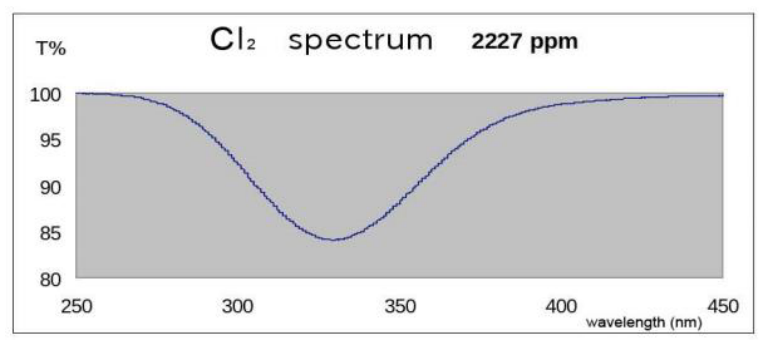

Fig. 1. Transmission spectrum of $\mathrm{Cl}_{2}$ in a spectral region $250-450 \mathrm{~nm}$.

a Corresponding author: 1konop@b10.vniim.ru

This is an Open Access article distributed under the terms of the Creative Commons Attribution License 4.0, which permits unrestricted use, distribution, and reproduction in any medium, provided the original work is properly cited. 


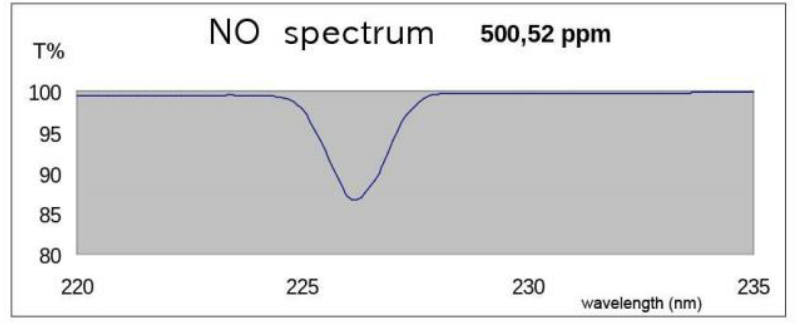

Fig. 2. Transmission spectrum of NO in a spectral region $220-235 \mathrm{~nm}$.

The analysis of measured spectra has shown that calibration curve can be expressed as:

$$
X_{\text {measi }}=\frac{t}{P \cdot L} \cdot \frac{k_{1} \cdot D}{1+\mathrm{k}_{2} \cdot D}
$$

where $k_{1}$ and $k_{2}$ - coefficients of calibration curve for a given wavelength $\lambda$ and given spectral resolution $\Delta \lambda$ in units and correspondingly, B - Bell unit; $L$ - cell optical path length (m); $P$ - pressure of analyzed binary gas mixture $(\mathrm{kPa})$, $t$ - temperature of analyzed binary gas mixture $(\mathrm{C}), \mathrm{D}-$ optical density.

The shape of calibration curve has been chosen on basis of analysis of dependence of optical density of investigated gas mixture on concentration at the chosen wavelengths and chosen spectral resolutions using measured spectra of CSs.

The coefficients of calibration curve $k_{1}$ and $k_{2}$ were computed at the stage of the procedure development.

Two cells with the optical lengths 150 and $20 \mathrm{~mm}$ were chosen to find coefficients of calibration curve by measuring spectra of CS. The optimal wavelength and spectral resolution were fitted for both cells.

The chosen parameters of the spectrometer are presented in table 1 .

Table 1. Parameters of the spectrometer chosen for the experiment.

\begin{tabular}{|c|c|c|c|c|c|}
\hline $\begin{array}{c}\text { Measured compo- } \\
\text { nent }\end{array}$ & $\begin{array}{l}\text { Range of mea- } \\
\text { surement, \% }\end{array}$ & $\begin{array}{l}\text { Length of a } \\
\text { cell, mm }\end{array}$ & $\begin{array}{l}\text { Optical length } \\
\text { of a cell, mm }\end{array}$ & $\begin{array}{c}\text { Monochromator } \\
\text { wavelength, } \lambda, \\
\mathbf{n m}\end{array}$ & $\begin{array}{c}\text { Spectral } \\
\underset{\mathbf{n m}}{\text { resolution, }}, \Delta \lambda,\end{array}$ \\
\hline \multirow[t]{2}{*}{ NO } & $\begin{array}{c}\text { from } 0.0050 \text { up } \\
\text { till } 0.25\end{array}$ & 150 & $130 \pm 10$ & \multirow[t]{2}{*}{226.2} & 1 \\
\hline & over 0.26 up till 3 & 20 & $10 \pm 0.5$ & & 1 \\
\hline \multirow[t]{2}{*}{$\mathrm{Cl}_{2}$} & $\begin{array}{c}\text { from } 0.05 \text { up till } \\
0.8\end{array}$ & 150 & $130 \pm 10$ & \multirow[t]{2}{*}{329.6} & 1 \\
\hline & over 0.8 up till 10 & 20 & $10 \pm 5$ & & 1 \\
\hline
\end{tabular}

The coefficients of calibration curve $k_{1}$ and $k_{2}$ are presented in table 2 .

Table 2 . The coefficients of calibration curve $k_{l}$ and $k_{2}$.

\begin{tabular}{|c|c|c|c|c|}
\hline $\begin{array}{c}\text { Measu- } \\
\text { red } \\
\text { com- } \\
\text { ponent }\end{array}$ & $\begin{array}{c}\text { Mono- } \\
\text { Chroma- } \\
\text { tor wave- } \\
\text { length, } \lambda, \\
\mathbf{n m}\end{array}$ & $\begin{array}{c}\text { Spectral } \\
\text { resolu- } \\
\text { tion, }\end{array}$ & $\begin{array}{c}\Delta \lambda, \mathbf{n m} \\
\text { Coeffi- } \\
\text { cient }\end{array}$ & $\begin{array}{c}\text { Coeffi- } \\
\text { cient }\end{array}$ \\
\hline $\mathrm{NO}$ & 226,2 & 1 & $2,882 \cdot 10^{-2}$ & $-1,61$ \\
\hline $\mathrm{Cl}_{2}$ & 329.6 & 1 & 0,1191 & 0 \\
\hline
\end{tabular}

Four CS for $\mathrm{Cl}_{2}$ with suitable mole fractions were chosen on basis of the analysis of measured spectra. So calibration curve was obtained with the use of CSs shown in table 1.

Five measurements $(N=5)$ of the transmission for $\mathrm{m}$-th $\mathrm{CS}$ and i-th measurement $T_{m, i}$ with a record of temperature $t_{m, i}$ and pressure $P_{m, i}$ of gas dmixture in a cell were conducted. Optical density was $D_{m, i}$ calculated for every i-th measurement:

$$
D_{\mathrm{m}, \mathrm{i}}=\log _{10}\left(T_{\mathrm{m}, \mathrm{i}}\right)
$$

Arithmetic means for $P_{m}$ and for m-th CS were calculated next. The next necessary criterion was checked:

$$
\frac{S\left(D_{m}\right)}{D_{m}} \cdot 100<0,2
$$

The criterion (3) was chosen on basis of analysis of precision at transitional stage of measurement of the transmission $\mathrm{T}$ with the use of the CS spectra. 
Points for plotting a calibration curve for every $\mathrm{CS} F_{m}$ was taken using an expression (4):

$$
F_{m}=\frac{X_{m} \cdot P_{m} \cdot L}{t}
$$

where $X_{m}(\%)$ - mole fraction of target component in the m-th CS.

The relative combined standard uncertainty of a calibration curve was calculated as:

$$
u_{F}^{0}=\sqrt{\left(u_{S}^{0}\right)^{2}+\frac{\delta_{C S}^{2}}{3}+\frac{\delta_{P}^{2}}{3}+\frac{\delta_{T}^{2}}{3}+\frac{U(L)^{2}}{3 \cdot L^{2}}}
$$

where $\delta_{\mathrm{CS}} \%$ - confidence limits of the error of mole fraction of a target component in $\mathrm{CS}, \delta_{P} \%$ - confidence limits on the relative error of an aneroid-barometer, $\delta_{T} \%$ - confidence limits on the relative error of a temperature sensor, $U(L) \mathrm{m}$, - expanded uncertainty of cell optical path length.

The procedure was developed as a result of the work done. The procedure was also certified. The procedure provides measurement results with the accuracy figures shown in table 3.

Table 3. Accuracy figures of the measurement procedure.

\begin{tabular}{|c|c|c|}
\hline $\begin{array}{c}\text { Target } \\
\text { component and } \\
\text { matrix* }\end{array}$ & $\begin{array}{c}\text { Measurement } \\
\text { range } \\
\text { of mole } \\
\text { fraction of } \\
\text { target component } \\
\text { in gas mixture, \% }\end{array}$ & $\begin{array}{c}\text { The relative } \\
\text { expanded } \\
\text { uncertainty of } \\
\text { measurement, } \\
\boldsymbol{U}^{\boldsymbol{0}}, \boldsymbol{\%} \\
\text { for coverage } \\
\text { factor } \boldsymbol{k}=\mathbf{2} * *\end{array}$ \\
\hline $\mathrm{NO}+\mathrm{N}_{2}$ & $\begin{array}{c}\text { from } 0.0050 \text { up } \\
\text { till } 3.0\end{array}$ & 1.1 \\
\hline $\mathrm{Cl}_{2}+\mathrm{N}_{2}$ & $\begin{array}{c}\text { from } 0.05 \text { up till } \\
10\end{array}$ & 0.8 \\
\hline
\end{tabular}

Footnote:

* Target component and matrix are indicated correspondently.

** Corresponds to confidence interval of the relative expanded uncertainty of measurement (for a level of confidence $P=0,95$ ).

The relative expanded uncertainty of measurement was calculated in accordance with [8].

\section{Conclusion}

As a result a procedure providing certification of two component gas mixtures of CSs was developed.

Application of modern spectrophotometers and development of measurement procedure on basis of UV absorption spectroscopy [7] ensures after its approbation transference of units of gas mixtures from the national primary measurement standard GET 1542011 to industrially manufactured working standards.

\section{References}

1. GOST 8.578 - 2008. State Hierarchy Scheme for the Instruments Measuring the Content of Components in Gas Media

2. Yu.S.Drugov, L.A.Konopelko, O.G.Popov. Control of air pollution of residential premises, offices, administrative and public buildings. St. Petersburg, Science, 2013, 302pp. Chapter 5.3.2. The standard base of the Russian Federation in the field of gas analysis. Контроль загрязнения воздуха жильх помещений, офисов, административных и общественных зданий. Санкт-Петербург, «Наука», 2013, 302 стр. Глава 5.3.2. Эталонная база РФ в области анализа газов (in Russian).

3. N. Jacquinet-Husson et al. J. Quant. Spectr. \& Rad. Transf. 1122395 (2011)

4. L.S. Rothman et al. J. Quant. Spectr. \& Rad. Transf. 110533 (2009)

5. S.P. Sander, J. Abbatt, J. R. Barker, J. B. Burkholder, R. R. Friedl, D. M. Golden, R. E. Huie, C. E. Kolb, M.

J. Kurylo, G. K. Moortgat, V. L. Orkin and P. H. Wine Chemical Kinetics and Photochemical Data for Use in Atmospheric Studies, Evaluation Number 17, JPL

Publication 10-6, Jet Propulsion Laboratory, Pasadena, 2011. http://jpldataeval.jpl.nasa.gov

6. Hannelore Keller-Rudek, Geert K. Moortgat, Rolf Sander, Rüdiger Sörensen. The MPI-Mainz UV/VIS Spectral Atlas of Gaseous Molecules of Atmospheric Interest www.uv-vis-spectral-atlas-mainz.org

7. Measurement procedure of mole fraction of components of $\left(\mathrm{NO}, \mathrm{Cl}_{2}\right)$ in gas mixtures. MИ 242/32014 Методика измерений молярной доли компонентов (NO, $\mathrm{Cl}_{2}$ ) в газовых смесях (in Russian). 8. EURACHEM/CITAC Guide. Quantifying Uncertainty in Analytical Measurement. Third Edition. Editors S L $\mathrm{R}$ Ellison (LGC, UK) A Williams (UK) http://www.citac.cc/QUAM2012 P1.pdf 